\title{
Quality of coffee beans from peeled green fruits after temporary immersion in water
}

\author{
Ana P. de F. Coelho ${ }^{1}$, Juarez de S. e Silva ${ }^{1}$, Antônio P. S. Carneiro ${ }^{2}$, Evandro de C. Melo르, \\ Camilla S. da Silva ${ }^{1}$ \& Cristiane F. Lisboa ${ }^{1}$ \\ ${ }^{1}$ Universidade Federal de Viçosa/Departamento de Engenharia Agrícola. Viçosa, MG, Brasil. E-mail: ana.p.coelho@ufv.br (Corresponding author) - ORCID: \\ 0000-0002-4144-8966; juarez@ufv.br - ORCID: 0000-0002-2230-7754; evandro@ufv.br - ORCID: 0000-0002-1418-8345; camilla.sena@ufv.br - ORCID: \\ 0000-0003-0845-5010; cflisboa.engenharia@gmail.com - ORCID: 0000-0002-9930-8800 \\ ${ }^{2}$ Universidade Federal de Viçosa/Departamento de Estatística. Viçosa, MG, Brasil. E-mail: policarpo@ufv.br - ORCID: 0000-0002-9043-3242
}

\begin{abstract}
The harvest of green coffee fruits affects their quality; they should be separated from the ripe fruits during processing. The proportion of harvested green fruits can be high, requiring information and technologies to adequately manage and add value to coffee beans from this fruit category. The objective of this work was to evaluate the quality of coffee beans from green fruits separated during a wet processing and peeled after temporary immersion in water. A completely randomized design was used, consisting of six treatments (ripe peeled coffee fruits dried on suspended yards, non-peeled green coffee fruits under traditional dry management on a concrete yard, and peeled and non-peeled green coffee fruits temporarily immersed in water and dried on suspended and concrete yards) and four replications, in the 2018 crop season. Samples of coffee beans temporarily immersed in water were peeled and separated into peeled and non-peeled fractions and dried in suspended and concrete yards. The peeling yield of green coffee beans and the physical and sensorial characteristics of the processed coffee beans were evaluated. The mean peeling yield was $62 \%$ and allowed the separation of more developed green fruits, equating them to ripe peeled coffee beans regarding physical and sensorial quality.
\end{abstract}

Key words: coffee production, post-harvest, immature fruits, coffee classification

\section{Qualidade de grãos de café oriundos de frutos verdes descascados após imersão temporária em água}

RESUMO: A colheita dos frutos de café verdes prejudica a qualidade final do produto, portanto devem ser separados dos frutos maduros durante o processamento. Como a proporção de frutos verdes colhidos pode ser alta, necessita-se gerar informações e tecnologias para o manejo adequado a fim de agregar valor aos grãos oriundos dessa categoria de frutos. Objetivou-se avaliar a qualidade dos grãos de café, oriundos de frutos verdes separados durante o processamento por via úmida e descascados após a imersão temporária em água. Utilizou-se o delineamento inteiramente casualizado com seis tratamentos (café cereja descascado e verde manejo tradicional secos em terreiro de concreto, verde imerso descascado e não descascados secos em terreiro de concreto e em terreiro suspenso) e quatro repetições, ao longo da safra de 2018. Após o descascamento da amostra imersa temporariamente, as frações descascadas e não descascadas foram divididas e secas em terreiro suspenso e de concreto. Avaliaram-se o rendimento do descascamento dos frutos verdes e as características físicas e sensoriais dos grãos beneficiados. O rendimento médio do descascamento foi de $62 \%$ e permitiu a segregação dos frutos verdes mais desenvolvidos, equiparando-os à qualidade física e sensorial do café cereja descascado.

Palavras-chave: cafeicultura, pós-colheita, frutos imaturos, classificação de café 


\section{INTRODUCTION}

Brazil leads the world production and export of arabica coffee (ICO, 2019). The international market established new directions for the Brazilian coffee production chain, considering socioenvironmental issues and product quality (Santos et al., 2008). Regarding the product quality, physical aspects of coffee beans and beverage from them are considered (Reis et al., 2011).

The maximum coffee bean quality is reached in the cherry stage, when the endosperm and chemical precursors are totally formed (Arruda et al., 2011). However, the flowering of coffee crops is uneven and the harvest is predominately non-selective; thus, green fruits are harvested together with the ripe ones (Custódio et al., 2012; Caldeira et al., 2017). According to Coelho et al. (2015), the high cost and scarcity of labor make a second fruit harvest unfeasible.

The wet processing separates the harvested green fruits, which are usually naturally dried. Considering that they are a low-value product for the market, they are managed secondarily, decreasing even more their coffee bean quality. The proportion of harvested green fruits can be high, mainly at the beginning of the harvest, thus requiring more information for their adequate management.

According to Marcomini (2011), peeling of coffee green fruits aggregates value to this product, decreases the volume to be handled, and optimizes the use of infrastructures and labor. However, few technical information is found for the peeling of green coffee fruits that are separated during the wet processing, without hindering the machinery or damaging the coffee beans (Borém et al., 2006).

Machado (2005) proposed a temporary immersion of coffee fruits as an alternative for the management of the difference between the harvest flow and the capacity of the processing units to maintain the coffee bean quality. The objective of this work was to evaluate the quality of coffee beans from green fruits separated during a wet processing.

\section{Material AND Methods}

Arabica coffee fruits were collected in a farm in the municipality of Paula Cândido, MG, Brazil (42 ${ }^{\circ} 54^{\prime} 56.7^{\prime \prime} \mathrm{W}$, $20^{\circ} 49^{\prime} 46.3^{\prime \prime} \mathrm{S}$, and altitude between 730 and $770 \mathrm{~m}$ ). The postharvest management of fruits practiced in the farm consisted in a wet processing using a peeler (LCS-1/OP-259; Pinhalense, Espírito Santo do Pinhal, Brazil). By the end of the processing, the fractions peeled beans, floater fruits, and non-peeled green fruits are dried in concrete yards. The drying of peeled coffee beans is finished in a rotary dryer.

The experiment was carried out in a completely randomized design with six treatments and four replications. The treatments consisted of ripe peeled coffee fruits dried in a suspended yard (RPF-SY); non-peeled green coffee fruits, under traditional drying management in a concrete yard, according to procedures used in the farm (NPGF-CY); peeled green coffee fruits temporarily immersed in water and dried in suspended yard (PGI-SY) and in concrete yard (PGI-CY); and non-peeled green coffee fruits temporarily immersed in water and dried in suspended yard (NPGI-SY) and concrete yard (NPGI-CY). The experiment was replicated once a week for four consecutive weeks, during the 2018 crop season.

Samples of coffee fruits were collected from the hopper of the peeler, discharge opening for peeled fruits, and non-peeled fruit receiver container. The fruit sample from the hopper, with volume of $1 \mathrm{~L}$, was cleaned and manually separated into overripe, ripe, and green to characterize the fruit maturation stage of the crop at the time of harvest. The ripe peeled coffee fruit sample (RPF), with volume of $8 \mathrm{~L}$, was used as control, indicating the maximum quality potential of the coffee under the crop conditions and post-harvest management adopted in the farm. Two samples were collected from the non-peeled fruit receiver container, one with volume of $10 \mathrm{~L}$ for the conventional treatment (NPGF), and other with mean volume of $215 \mathrm{~L}$ for the treatments with fruits temporarily immersed in water (IW).

The collected samples (RPF, NPGF, and IW) were taken to the Pre-Processing Area for Agricultural Products of the Department of Agricultural Engineering of the Federal University of Viçosa, in Viçosa, MG, Brazil, where the experiment was conducted.

The samples for RPF and NPGF were immediately distributed over suspended yards, making a layer of approximately $5 \mathrm{~cm}$. These yards consisted of structures made of wood and nylon screen arranged in a ventilated place, practically shaded, and protected from rainfall. The samples were upturned four times a day until reach $12 \%$ water content.

The application of the treatment with temporary immersion in water to the IW samples was carried out using the methodology proposed by Machado (2005). The green fruits were placed in 500-liter polyethylene containers and immersed in potable water. The containers remained uncovered, in a practically shaded and ventilated place for seven days. The water was exchanged daily in the morning period.

After temporarily immersion in water, the fruits were peeled in a peeler (D120SV-64B; Serafim Blasi, Botucatu, Brazil). The peeling yield was calculated following the methodology used by Nobre (2009), which considers the difference between the initial volume and the non-peeled final volume, as shown by Eq. 1:

$$
\mathrm{nd}=\frac{\mathrm{V}_{\mathrm{t}}-\mathrm{V}_{\mathrm{np}}}{\mathrm{V}_{\mathrm{t}} 100}
$$

where:

nd - peeling yield (\%);

$\mathrm{V}_{\mathrm{t}} \quad$ - total volume (L); and,

$\mathrm{V}_{\mathrm{np}}$ - non-peeled fruit volume (L).

After the peeling, the two resulting fractions were divided into peeled (PGI) and non-peeled (NPGI) green fruits immersed in water, which were placed on suspended yard (PGI-SY and NPGI-SY) and on concrete yard (PGI-CY and NPGI-CY), both located in practically shaded ventilated places protected from rainfall. The samples were upturned four times a day during the drying period.

When the fruits reached a water content lower than $13 \%$ (wet basis), the coffee fruit samples of the treatments (RPF-SY, 
NPGF-CY, PGI-SY, PGI-CY, NPGI-SY, and NPGI-CY) were processed using a peeler (DRC 2/3823; Pinhalense, Espírito Santo do Pinhal, Brazil). The samples were then packaged, identified, and arranged in a ventilated place protected from light and moisture, until the physical and sensorial analyses.

The physical and sensorial characteristics of the processed coffee beans were evaluated based on the variables listed in the Identity and Quality Technical Regulations for Processed Coffee Classification (Raw Grains) of the Normative Instruction no. 8 of June 11, 2003 (classification by 16-sieve, hectoliter weight, classification by type, and sensorial analysis of the beverage) established by the Brazilian Ministry of Agriculture, Livestock, and Supply (IN8-MAPA); and on the physical quality index described by Coelho (2019). The analyses were carried out using the following procedures:

- Classification of beans by the 16-sieve: $500 \mathrm{~g}$ of raw coffee beans were passed through a 16-sieve; the sieving standard adopted consisted of 16 cross movements. The ratio between the weight of beans retained in the sieve and the initial weight of the sample was transformed into percentage. The procedures were done in triplicate, considering the mean value.

- Hectoliter weight: measured in a balance (40-822; Dallemolle, Caxias do Sul, Brazil), in triplicate, considering the mean value.

- Classification by type: defined by evaluating the quantities of defective beans and impurities in the processed coffee samples. The values were weighed and the total was considered to classify them into types using the Equivalence Tables present in the IN8-MAPA. The samples were analyzed in the Brazilian National Center for Training in Storage (CENTREINAR) by classifiers of the Brazilian National Service for Rural Learning (SENAR).

- Sensorial analysis of the beverage: evaluated according to the protocol of the Specialty Coffee Association (SCA), considering the following characteristics: aroma, flavor, acidity, body, aftertaste, balance, final taste, sweetness, cleanness, uniformity, and defects to calculate the overall grade. The samples were analyzed at the Federal Institute of Espírito Santo, campus Venda Nova do Imigrante, ES, Brazil, by four $\mathrm{Q}-$ Grader of the institution. The mean of overall grades given by each professional was considered.

- Physical quality index (PQI): the maximum possible PQI for a sample is 14, which indicates a coffee with excellent physical quality; and values below 7 indicate a coffee with low physical quality (Coelho, 2019). A sample of $300 \mathrm{~g}$ of raw coffee beans from the 16-sieve was used. The beans that passed through and those retained in the 16-sieve were weighed separately, and 100 random seeds were collected manually and weighed to obtain the final PQI, using Eqs. 2 and 3:

$$
\begin{gathered}
\mathrm{PQI}=\frac{\mathrm{P}_{16} \mathrm{Pm}_{100}}{300} \\
\mathrm{PMP}=\frac{\% \mathrm{P}_{16} \mathrm{P}_{16100 \mathrm{~s}}+\% \mathrm{P}_{15} \mathrm{P}_{15100 \mathrm{~s}}}{100}
\end{gathered}
$$

where:

$\mathrm{P}_{16}$ - weight of beans retained in the 16-sieve $(\mathrm{g})$;
$\mathrm{P}_{15}$ - weight of beans that passed through the 16-sieve (g);

$\mathrm{PMP}_{100}$ - mean weighted weight of 100 beans $(\mathrm{g})$;

$\mathrm{P} 16_{100 \mathrm{~s}}$ - weight of 100 beans retained in the 16- sieve (g); and,

P15 100 s - weight of 100 beans that passed through the 16-sieve (g).

The characterization of the coffee bean maturation stage and the peeling yield data were subjected to descriptive statistical analysis. The data of the physical and sensorial variables of processed beans were subjected to analysis of variance (ANOVA). When the means of the treatments were significant, they were subjected to the Duncan test at $\mathrm{p} \leq 0.05$.

\section{Results AND Discussion}

Regarding the maturation stage of the coffee fruits harvested during the 2018 crop season, the mean percentages of green fruits found in the hopper in the replication were $22.7 \%, 20.05 \%, 10.015$, and $19.2 \%$ (overall mean $=18.1 \%$; CV $=30.6 \%)$. According to Reis et al. (2011), the harvest should begin when the percentage of green fruits is equal to or lower than $5 \%$ to obtain good quality coffee, since they decrease the beverage quality and cause quantitative losses. Therefore, the separation and adequate management of green fruits are interesting for coffee growers.

No unpleasant aroma or characteristic was found in the samples over the immersion period. The low temperature of the water due to the cold, dry winter in the microregion of Viçosa may have contributed for the conservation of fruits, preventing fermentative processes. However, variations were found in the color of the fruits and water, which acquired brownish shades.

The color variation can be explained by the leaching of chemical components from the fruits to the water, as also observed by Machado (2005), who reported that the color variation can be used as an attribute to differentiate batches during temporary immersions and identify batches that already underwent some qualitative loss by undesirable fermentation. The water chemical composition analysis after the temporary immersion of fruits may show the possibility of using this water for fertigation, as well as the coffee processing wastewater (Reis et al., 2011).

The mean peeling yield of green fruits after the temporary immersion was $62 \%$, with coefficient of variation of $7 \%$. This is an intermediate value compared to those found in the literature. Nobre (2009) found mean yield of 57\% after reprocessing coffee green fruits that were immersed in water for 12, 24, and 48 hours; and Coelho (2019) found peeling yield of $70 \%$ for green fruits that were immersed in water for seven days.

A precise determination of peeling yield should consider the composition of the fraction of non-peeled fruits, as found by Coelho (2019). This fraction consisted of resistant fruits to peeling; fruits that were peeled, but remained with the two faces of the beans united and did not pass through the mesh of the sieve; and low-size fruits that passed through the sieve mesh together with the peeled beans, but were separated afterwards. Therefore, adaptations in the device can result in a higher peeling yield. 
The injuries caused in the pericarp of green coffee beans during the passing of the fruits through the peeler, shown by the immediate oxidation of fruits after the processing, may have contributed to the softening of the pericarp during the immersion in water. The decrease in mechanical resistance of the peel and pericarp facilitated their removal during the peeling. Therefore, the proposal of taking the green coffee beans that were separated in the processing and immerging them in water, following the presented methodology, is an alternative for an effective peeling.

The peeling of coffee green fruits after temporary immersion in water significantly affected their hectoliter weight, number of defects, and sensorial analysis (Table 1). The mean values for the physical characteristics and sensorial analysis that presented significant differences are presented in Table 2.

The coffee used in the presented study had, in general, low potential quality. The combination of environmental effects, plant variety, processing phases, drying, and temporary immersion in water are among the factors that most affected the coffee quality (Zaidan et al., 2017; Santos et al., 2017).

The coffee from the treatments RPF-SY, PGI-SY, and PGI-CY presented the best quality characteristics (Table 2). This result can be explained by the separation of larger fruits during the wet processing, mainly in the peeling step, which resulted in differences in the variables hectoliter weight and number of defects. The more developed the fruit, the greater the dry matter accumulation and the higher the endosperm quality (Saraiva et al., 2010; Reis et al., 2011; Lima Filho et al., 2013).

The lowest hectoliter weights were found for the treatments NPGI-SY and NPGI-CY, which presented, in general, less developed fruits. The treatment NPGF-CY also presented

Table 1. Analysis of variance for percentage of coffee beans retained in the 16-sieve (PB16), hectoliter weight (HW), physical quality index (PQI), number of defects (ND), and sensorial analysis (SA)

\begin{tabular}{ccccccc}
\hline Source & & \multicolumn{5}{c|}{ Mean square } \\
\cline { 2 - 7 } of variation & DF & PB16 & HW & PQI & ND & SA \\
\hline Treatment & 5 & $64.46^{\text {ns }}$ & $12.25^{*}$ & $1.53^{\text {ns }}$ & $197534.84^{*}$ & $5.61^{*}$ \\
Residue & 18 & 30.92 & 1.79 & 0.90 & 22950.82 & 1.24 \\
CV $(\%)$ & - & 8.78 & 2.14 & 13.87 & 38.87 & 11.45 \\
\hline DF - Degrees of freedom* * Significant at $\mathrm{p} \leq 0.05$ by the F test. ns - Not significant
\end{tabular}

DF - Degrees of freedom; ${ }^{*}$ - Significant at $\mathrm{p} \leq 0.05$ by the F test; ns - Not significant

Table 2. Mean hectoliter weight (HW), number of defects (ND), and sensorial analysis (SA) of coffee fruits under different processing treatments

\begin{tabular}{|c|c|c|c|}
\hline Treatment & $\begin{array}{c}H W \\
\left(\mathrm{~kg} 100 L^{-1}\right)\end{array}$ & $\begin{array}{c}\text { ND } \\
\text { (un } 300 g^{-1} \text { ) }\end{array}$ & SA \\
\hline RPF-SY & $64.24 a$ & $149.50 \mathrm{~b}$ & $78.06 \mathrm{a}$ \\
\hline NPGF-CY & $62.46 a b$ & $523.30 \mathrm{a}$ & $74.94 b$ \\
\hline PGI-SY & $63.36 \mathrm{a}$ & $156.50 \mathrm{~b}$ & $77.97 \mathrm{a}$ \\
\hline PGI-CY & $63.49 a$ & $289.00 \mathrm{~b}$ & $77.53 \mathrm{a}$ \\
\hline NPGI-SY & $59.90 \mathrm{C}$ & $540.00 \mathrm{a}$ & $76.59 \mathrm{ab}$ \\
\hline NPGI-CY & $60.49 \mathrm{bc}$ & $680.00 \mathrm{a}$ & $76.47 \mathrm{ab}$ \\
\hline
\end{tabular}

Means followed by the same letters in the columns are not different by the Duncan test at $\mathrm{p} \leq 0.05$; RPF-SY - Ripe peeled coffee fruits dried in a suspended yard; NPGF-CY Non-peeled green coffee fruits, under traditional drying management on concrete yard; PGI-SY - Peeled green coffee fruits temporarily immersed in water and dried on suspended yard; PGI-CY - Peeled green coffee fruits temporarily immersed in water and dried on concrete yard; NPGI-SY - Non-peeled green coffee fruits temporarily immersed in water and dried on suspended yard; NPGI-CY - Non-peeled green coffee fruits temporarily immersed in water and dried on concrete yard higher hectoliter weight, which can be explained by the dilution of less developed beans.

The results for number of defects in each treatment showed a promising effect of the peeling of green fruits. According to the IN8-MAPA, which establishes technical regulation for identity and quality for coffee classification, the samples of the treatments RPF-SY, PGI-SY, and PGI-CY were classified as Type 6, Type 6, and Type 7, respectively. In addition, samples of the treatments NPGF-CY, NPGI-SY, and NPGI-CY would be declassified because of their type class by presenting high number of defects. Therefore, the peeling of green fruits after temporary immersion in water directly affected the bean quality after processing by removing defected beans that would declassify the batch.

The sensorial analysis showed best means of overall grade for the treatments RPF-SY, PGI-SY, and PGI-CY, respectively (Table 2). The analysis of variance of grades for the attributes in the sensorial analysis showed that the treatments affected significantly the acidity, balance, aftertaste, and body of the beverage. Table 3 shows the mean values found for each evaluated attribute in the sensorial analysis.

The coffee from fruits in the treatment NPGF-CY had the lowest means for acidity, body, aftertaste, and balance and, thus, the lowest sensorial overall grade. The other treatments presented similar means for body, aftertaste, and balance. The highest mean acidity was found in fruits from the treatment PGI-CY. Therefore, the results indicated that the temporary immersion in water and the peeling of green fruits affected positively the attributes evaluated in the sensorial analysis based on the Specialty Coffee Association.

Changes in chemical composition of green fruits after temporary immersion in water were also reported by Nobre et al. (2011), who found that the peeling improved physiological and chemical characteristics related to the quality of the beverage. According to Velmourougane (2011), the immersion of beans in water promotes the leaching of chemical compounds, such as diterpenes, polyphenols, and tannins, responsible for the bitterness and darkening of beans, which can be intensified by addition of organic acids.

The changes in the color of the fruits and water throughout the immersion period denote the leaching of some chemical compounds. According to Abreu et al. (2015), processing operations and immersion conditions can change the color of coffee beans. The more intense green color in the treatment

Table 3. Mean values for acidity, body, aftertaste, and balance of coffee from fruits under different processing treatments

\begin{tabular}{|ccccc}
\hline Treatments & Acidity & Body & Aftertaste & Balance \\
\hline RPF-SY & $6.72 \mathrm{~b}$ & $7.00 \mathrm{a}$ & $6.56 \mathrm{ab}$ & $7.00 \mathrm{a}$ \\
NPGF-CY & $6.38 \mathrm{c}$ & $6.38 \mathrm{~b}$ & $6.06 \mathrm{c}$ & $6.36 \mathrm{~b}$ \\
PGI-SY & $6.72 \mathrm{~b}$ & $6.90 \mathrm{a}$ & $6.69 \mathrm{ab}$ & $7.00 \mathrm{a}$ \\
PGI-CY & $7.02 \mathrm{a}$ & $6.84 \mathrm{a}$ & $6.38 \mathrm{bc}$ & $6.81 \mathrm{ab}$ \\
NPGI-SY & $6.47 \mathrm{bc}$ & $6.69 \mathrm{ab}$ & $6.35 \mathrm{bc}$ & $6.81 \mathrm{ab}$ \\
NPGI-CY & $6.66 \mathrm{~b} \mathrm{c}$ & $6.66 \mathrm{ab}$ & $6.35 \mathrm{ab}$ & $6.88 \mathrm{ab}$ \\
\hline
\end{tabular}

Means followed by the same letters in the columns are not different by the Duncan test at $\mathrm{p} \leq 0.05$; RPF-SY - Ripe peeled coffee fruits dried in a suspended yard; NPGF-CY Non-peeled green coffee fruits, under traditional drying management on concrete yard; PGI-SY - Peeled green coffee fruits temporarily immersed in water and dried on suspended yard; PGI-CY - Peeled green coffee fruits temporarily immersed in water and dried on concrete yard; NPGI-SY - Non-peeled green coffee fruits temporarily immersed in water and dried on suspended yard; NPGI-CY - Non-peeled green coffee fruits temporarily immersed in water and dried on concrete yard 
NPGF-CY confirms the effect of immersion on the physical characteristics of processed beans. The composition of the waters used for immerging the green coffee fruits and the identification of leaching compounds are issues that can be discussed in further researches.

The two drying locations evaluated, suspended and concrete yards, showed no significant differences. However, Reinato et al. (2011) reported that the quality of coffee from fruits dried in yards is affected by the yard type, drying layer thickness, and processing type used. The drying of green coffee fruits should be slow to avoid the darkening of the grains, which is considered a defect by classification standards, regardless of the drying method (Silva et al., 2008).

Considering the results found in the observations in the analyses throughout the experiment and the information found in the literature, the peeling of green coffee fruits after temporary immersion in water can add value to the product. Coffee beans in parchment have higher market value, and the removal of the peel contributes to decrease the time and space required for drying. Moreover, the optimization of machinery and labor can be an additional advantage to the application of the proposed technique (Marcomini, 2011).

However, no technique that includes the peeling of green coffee fruits justifies a premature harvest. The possibility of immerging the fruits in water for subsequent peeling should be an alternative to facilitate the organization of post-harvest operations and the separation of beans with defects that could hinder the quality of the product. Therefore, coffee growers can, simultaneously, add value to their coffee and optimize the resources invested in the crop.

\section{Conclusions}

1. The peeling yield of green coffee fruits temporarily immersed in water was $62 \%$.

2. The coffee from green fruits immersed in water before peeling presented significantly similar beverage quality, hectoliter weight, and number of defects to those of beans from ripe fruits.

3. The temporary immersion of green coffee fruits in water before peeling improves the beverage acidity and body when compared to green coffee fruits processed with the traditional management.

4. The physical and sensorial characteristics of peeled and non-peeled coffee fruits immersed in water before peeling and dried on suspended and concrete yards presented no significant differences.

\section{ACKNOWLedgements}

This study was partially financed by the site www. poscolheita.com.br, the Concelho Nacional de Desenvolvimento Científico e Tecnológico - Brasil (CNPq), the Coordenação de Aperfeiçoamento de Pessoal de Nível Superior - Brasil (CAPES) - Finance Code 001, and the Fundação de Amparo à Pesquisa do Estado de Minas Gerais (FAPEMIG). The authors thank Mr. Edson Alemão, and the Universidade Federal de Viçosa, for providing the area and raw materials for this study.

\section{Literature Cited}

Abreu, G. F.; Pereira, C. C.; Malta, M. R.; Clemente, A. C. S.; Coelho, L. F. S.; Rosa, S. D. V. F. Alterações na coloração de grãos de café em função das operações pós-colheita. Coffee Science, v.10, p.429-436, 2015.

Arruda, N. P.; Hovell, A. M. C.; Rezende, C. M.; Freitas, S. P.; Sonia Couri, S.; Bizzo, H. R. Discriminação entre estádios de maturação e tipos de processamento de pós-colheita de cafés arábica por micro extração em fase sólida e análise de componentes principais. Química Nova, v.34, p.819-824, 2011. https://doi.org/10.1590/ S0100-40422011000500017

Borém, F. M.; Reinato, C. H. R.; Silva, P.; Faria, L. F. Processamento e secagem de frutos verdes de cafeeiro. Brasileira de Armazenamento, v.9, p.19-24, 2006.

Caldeira, L. G.; Sette, R. S.; Portugal, N. S.; Fonseca, A. S.; Garcia, G. F. R. Café arábica do Brasil: O problema da imagem e a consequência no preço. Universidade Vale do Rio Verde, v.15, p.717-726, 2017. https://doi.org/10.5892/ruvrd.v15i1.3598

Coelho, A. L. F; Santos, F. L.; Pinto, F. A. C.; Queiroz, D. M. Determinação das propriedades geométricas, físicas e mecânicas do sistema fruto-pedúnculo-ramo do cafeeiro. Engenharia Agrícola e Ambiental, v.19, p.286-292, 2015. https://doi. org/10.1590/1807-1929/agriambi.v19n3p286-292

Coelho, A. P. F. Produção de café (Coffea arabica L) em pergaminho oriundo de frutos verdes após imersão temporária em água. Viçosa: UFV, 2019. 63p. Dissertação Mestrado.

Custódio, A. A. P.; Rezende, F. C.; Faria, M. A.; Morais, A. R.; Guimarães, R. J.; Scalco, M. S. Florescimento da lavoura cafeeira sob diferentes manejos de irrigação. Coffee Science, v.7, p.20-30, 2012.

ICO - International Coffee Organization. Relatório sobre o mercado cafeeiro. London: IOC, 2019. 7p.

Lima Filho, T. L.; Lucia, S. M. D.; Saraiva, S. H.; Sartori, M. A. Composição físico-química e qualidade sensorial de café conilon produzido no Estado do Espírito Santo e submetido a diferentes formas de processamento. Semina Ciências Agrárias, v.34, p.17231730, 2013. https://doi.org/10.5433/1679-0359.2013v34n4p1723

Machado, M. C. Viabilidade da técnica de imersão para armazenagem temporária dos frutos de café. Viçosa: UFV, 2005. 103p. Tese Doutorado

Marcomini, G. R. Café verde descascado: Análise econômicofinanceira comparada ao processamento natural. Informações Econômicas, v.41, p.1-10, 2011.

Nobre, G. W. Processamento e qualidade de frutos verdes de café arábica. Lavras: UFLA, 2009. 97p. Tese Doutorado

Nobre, G. W.; Borém, F. M.; Isquierdo, E. P.; Pereira, G. R. F. Composição química de frutos imaturos de café arábica (Coffea arabica L.) processados por via seca e via úmida. Coffee Science, v.6, p.107-113, 2011.

Reinato, C. H. R.; Borém, F. M.; Cirillo, M. A.; Oliveira, E. C. Qualidade do café secado em terreiros com diferentes pavimentações e espessuras de camada. Coffee Science, v.7, p.223-237, 2011.

Reis, P. R.; Cunha, R. L.; Carvalho, G. R. Café arábica - Da pós-colheita ao consumo. Lavras: EPAMIG, 2011. 734p.

Santos, J. C. F.; Raij, B.; Lima, A. J.; Afonso Júnior, P. C. A. Avaliação de conformidades de cafeicultores do cerrado mineiro sobre exigências da produção integrada de café. Coffee Science, v.3, p.7-18, 2008. 
Santos, O. L.; Reinato, C. H. R.; Junqueira, J. D.; Franco, E. L.; Souza, C. W. A.; Rezende, A. N. Custo-benefício da secagem de café em diferentes tipos de terreiro. Agrogeoambiental, v.9, p.11-21, 2017. https://doi.org/10.18406/2316$1817 \mathrm{v} 9 \mathrm{n} 42017966$

Saraiva, S. H.; Zeferin, L. B.; Lucia, S. M. D.; Teixeira, L. J. Q.; Junqueira, M. S. Efeito do processamento pós-colheita sobre a qualidade do café conillon. Enciclopédia Biosfera, v.6, p.1-9, 2010 .
Silva, J. S.; Afonso, A. D. L.; Donzeles, S. M. L.; Nogueira, R. M. Secagem e secadores. In: Silva, S. J. Secagem e armazenagem de grãos no Brasil. Viçosa: Aprenda Fácil Editora. Cap.5, 2008. p.107-138.

Velmourougane, K. Effects of wet processing methods and subsequent soaking of coffee under different organic acids on cup quality. World Journal of Science and Technology, v.7, p.32-38, 2011.

Zaidan, U. R.; Corrêa, P.C.; Ferreira, W. P. M.; Cecon, P. R. Ambiente e variedades influenciam a qualidade de cafés das Matas de Minas. Coffee Science, v.12, p.240-247, 2017. https://doi.org/10.25186/cs.v12i2.1256 